\title{
STANOWISKA WYBRANYCH PAŃSTW REGIONU BLISKIEGO WSCHODU WOBEC ZMIAN POLITYCZNYCH W EGIPCIE. WPLYW NA OBECNY STAN STOSUNKÓW DWUSTRONNYCH ${ }^{1}$
}

Nie ulega wątpliwości, że proces zmian politycznych w Egipcie, zainicjowany w styczniu 2011 r., ma znaczenie nie tylko wewnętrzne, ale także regionalne. Po pierwsze, stanowi element szerszego procesu zmian w wielu państwach obszaru MENA. Po drugie, zmiana władz w Egipcie wpłynęła, między innymi, na reorientację w ramach egipskiej polityki zagranicznej, w tym na relacje dwustronne z różnymi aktorami regionalnymi. Po trzecie, powróciła kwestia regionalnej mocarstwowości Egiptu, a zwłaszcza rywalizacji o prymat w świecie arabskim.

Przedmiot niniejszego artykułu stanowi szczegółowa analiza stanowisk władz najważniejszych państw bliskowschodnich, w odniesieniu do zmian na egipskiej scenie politycznej po 2011 r.: Izraela, Turcji, Islamskiej Republiki Iranu oraz państw członkowskich Rady Współpracy Zatoki Perskiej - Arabii Saudyjskiej, Bahrajnu, Zjednoczonych Emiratów Arabskich, Kataru, Omanu i Kuwejtu. Celem artykułu jest ustalenie przyczyn, dla których władze wyżej wymienionych państw zdecydowały się, bądź też nie, udzielić poparcia dla zmian politycznych w Egipcie w latach 2011 i 2013, a także konsekwencji tych decyzji z perspektywy 2015 r. Podstawowe pytanie badawcze dotyczy zależności pomiędzy decyzjami podjętymi przez poszczególne państwa w odniesieniu do zmian politycznych w Egipcie a obecnym stanem stosunków dwustronnych. Podstawę źródłową stanowią wybrane monografie, artykuły naukowe, analizy, materiały prasowe oraz źródła internetowe.

Należy zauważyć, iż poza Izraelem, wszystkie wyżej wymienione państwa charakteryzują albo autorytarna forma rządów (Arabia Saudyjska, Iran, Bahrajn, Katar, Zjednoczone Emiraty Arabskie, Oman, Kuwejt), albo przynajmniej poważny deficyt demokracji oraz stosowanie represji wobec opozycji (Turcja). Sukces egipskiej rewolucji mógł stanowić zachętę dla sił opozycyjnych w wymienionych państwach i w rezultacie doprowadzić do wybuchu niepokojów społecznych, a jednak niektóre z nich otwarcie opowiadały się za odsunięciem od władzy Hosni Mubaraka. Równie istotna była ich reakcja na zamach stanu i odsunięcie od władzy reprezentantów Bractwa Muzułmańskiego, w tym prezydenta Mursiego, w lipcu 2013 r. Jakie były przyczyny i jakie są konsekwencje tych decyzji?

1 Prezentowane badania były prowadzone w ramach projektu finansowanego przez Narodowe Centrum Nauki (decyzja 2012/05/B/HS5/005). 


\section{STANOWISKO IZRAELSKIE}

Analizę stanowisk najważniejszych państw regionu względem przemian politycznych w Egipcie warto rozpoczać od izraelskiego, które jest najbardziej złożone zarówno ze względów historycznych i politycznych, jak również gospodarczych. Bez wątpienia to właśnie Izrael był tym państwem, które na zmianie władz w Egipcie mogło stracić najwięcej. Od czasu podpisania układu pokojowego w Camp David w 1978 r., Egipt i Izrael łączyły dobre stosunki. W okresie rządów Hosni Mubaraka oba państwa współpracowały ze sobą zarówno na płaszczyźnie politycznej, jak i gospodarczej. Najlepszy przykład stanowiła zawarta w 2005 r. egipsko-izraelska umowa, dotycząca budowy podmorskiego gazociagu i dostaw gazu z Egiptu do Izraela. Zresztą okoliczności jej zawarcia zostały wykorzystane w późniejszym akcie oskarżenia przeciwko Hosni Mubarakowi.

Tym samym gwałtowne antyrządowe wystąpienia w Egipcie wywołały duże zaniepokojenie władz izraelskich. Odsunięcie od władzy prezydenta Mubaraka wiązało się z dużym prawdopodobieństwem wyraźnego pogorszenia wzajemnych stosunków, a w przypadku dojścia do władzy członków Bractwa Muzułmańskiego lub islamistów, doprowadzić do zerwania stosunków dyplomatycznych. Ponadto, niekontrolowany rozwój wydarzeń w Egipcie mógł zagrozić pokojowi w regionie i doprowadzić do ponownego, prawie całkowitego, geopolitycznego otoczenia Izraela przez wrogie arabskie reżimy. W związku z powyższym, izraelskie władze poważnie obawiały się powrotu do sytuacji sprzed 1978 r. Nota bene, taki scenariusz zagrażał także trwałości regionalnej struktury bezpieczeństwa, której architektem i głównym promotorem, od momentu zawarcia porozumienia w Camp David, pozostawały Stany Zjednoczone. Współpraca egipsko-izraelska stanowiła jeden z jej najważniejszych elementów.

W rezultacie można stwierdzić, iż na izraelskie stanowisko w sprawie zmian politycznych w państwach arabskich decydujący wpływ miała szczególna pozycja Izraela w regionie, a zwłaszcza niekorzystne położenie geopolityczne. Egipt, obok Jordanii, był jedynym państwem regionu współpracującym z Izraelem. Według Itamara Rabinovicha, „Izrael spogląda na arabską wrzawę niczym przez popękane szkła, te, które znamionują silne, ale jednocześnie zaniepokojone państwo; szkła ważnego aktora bliskowschodniej sceny politycznej, które nie jest w pełni zintegrowane z regionem; szkła państwa, które utrzymuje pokojowe relacje z niektórymi arabskimi państwami, a jednocześnie jest $\mathrm{w}$ konflikcie nie tylko z pozostałymi, ale całym światem muzułmańskim" (Rabinovich, 2014: 1). Przy okazji należy jednak wyraźnie podkreślić, iż egipska opozycja nie zabiegała o poparcie ze strony Izraela. Wręcz przeciwnie. Ewentualne wsparcie Tel Awiwu mogłoby zdyskredytować jej członków nie tylko w oczach wielu Egipcjan, ale także w świecie arabskim.

Obawy strony izraelskiej najpełniej wyraził prezydent Shimon Peres, który, kilka miesięcy po ustąpieniu prezydenta Mubaraka, podziękował mu za to, że uchronił państwo przed wojną. Jednocześnie, co znamienne, oświadczył: „Wybory w Egipcie stanowią niebezpieczeństwo. Ewentualny wybór Bractwa Muzułmańskiego nie przyniesie pokoju. Demokracja bez pokoju nie jest demokracją. Obawiamy się, że będzie miała miejsce zmiana rządzących, bez jednoczesnej zmiany okoliczności, które doprowadziły [Egipt - przyp. P.O.] do tego stanu" (Peres praises, 2011). Ostateczny sukces 
opozycji w lutym 2011 roku nie zapowiadał jednak istotnych zmian w kontaktach z Izraelem. Dopiero wzrost politycznego znaczenia Bractwa Muzułmańskiego i wreszcie przejęcie przezeń władzy stworzyły realne zagrożenie dla współpracy egipsko-izraelskiej. „Od momentu upadku reżimu Mubaraka, w Izraelu powszechne było przekonanie, iż jakikolwiek islamistyczny rząd w Egipcie będzie koniecznie wrogo nastawiony względem żydowskiego państwa. Wybory parlamentarne w Egipcie, wygrane przez Bractwo Muzułmańskie z wynikiem bliskim 50\%, jedynie wzmocniły to przekonanie, a premier Netanjahu podchodził do nich podejrzliwie, zgodnie z zasadą poczekamy - zobaczymy. Z drugiej strony, powiązana z Bractwem zwycięska Partia Wolności i Sprawiedliwości także nie zamierzała zmienić swego stanowiska wobec, jak to określano, syjonistycznego podmiotu" (Ben-Meir, 2014: 51). Przewidywania izraelskich władz zaczęły się sprawdzać w kwietniu 2012 r., gdy władze Egiptu zerwały zawarty na okres 20 lat kontrakt na dostawy gazu do Izraela. Już przedtem gazociag przebiegający przez półwysep Synaj stał się celem kilkunastu sabotażowych ataków, a w wielu miastach odbywały się demonstracje przeciwników egipsko-izraelskiej współpracy (Adib-Moghaddam, 2014: 4). Wielu Egipcjan było przekonanych, że na podstawie niekorzystnych warunków umowy z 2005 r., Izraelczycy kupowali od nich gaz znacznie poniżej cen rynkowych. Izrael zareagował jednak powściagliwie. W odpowiedzi na decyzję strony egipskiej, minister spraw zagranicznych Izraela, Avigdor Lieberman, oświadczył: „To nie jest dobry znak, ale moim zdaniem przekształcenie sporu gospodarczego w spór dyplomatyczny byłoby błędem" (Sherwood, 2012). Współpraca została jednak dość szybko wznowiona, po przejęciu władzy w Egipcie przez prezydenta Sisiego.

Odsunięcie od rządów Bractwa Muzułmańskiego było bardzo korzystne dla Izraela nie tylko ze względów politycznych i ekonomicznych, ale także z punktu widzenia bezpieczeństwa państwa. Izraelczykom udało się uniknąć ponownego okrążenia przez wrogie arabskie reżimy. Nie bez znaczenia pozostawał także fakt, iż nowe władze Egiptu nie zamierzały współpracować z Iranem, jak miało to miejsce w okresie prezydentury Muhammada Mursiego.

\section{TURCJA WOBEC PRZEMIAN NA EGIPSKIEJ SCENIE POLITYCZNEJ}

Dojście do władzy w Turcji w 2002 r. Partii Sprawiedliwości i Rozwoju (AKP) zaowocowało istotną zmianą w polityce zagranicznej Turcji. W ramach koncepcji tworzenia tak zwanej strategicznej głębi (tur. stratejik derinlik) ważną rolę odgrywało wyeliminowanie problemów w relacjach dwustronnych z państwami sąsiednimi, w tym także z Syrią (Davutoğlu, 2001). Jednocześnie nowe władze zamierzały odtworzyć dawną, osmańską sferę wpływów poprzez normalizację stosunków lub pogłębienie współpracy z państwami na obszarze Afryki Północnej oraz na Bliskim Wschodzie, a także dalej w Afryce i Azji. W przypadku Egiptu, Turcja liczyła na pogłębienie dotychczasowej współpracy.

Turecka koncepcja polityki zagranicznej, autorstwa Ahmeta Davutoğlu, była oceniana jako projekt konstruktywny i ambitny. Zwracano uwagę, iż dzięki niemu Turcja może odegrać rolę aktora stabilizującego sytuację w regionie, o czym świadczyło, mię- 
dzy innymi, jej zaangażowanie w próbę zbliżenia izraelsko-syryjskiego. Jak słusznie zauważył Graham E. Fuller, ,nigdy przedtem współczesne państwo tureckie nie było tak zaangażowane w sprawy Bliskiego Wschodu" (Fuller, 2014: 4).

Wydarzenia w świecie arabskim z przełomu 2010 i 2011 r. stanowiły jednak dla władz Turcji, podobnie jak dla władz wielu innych państw, duże zaskoczenie. Przez blisko dekadę podstawę dobrych relacji z poszczególnymi państwami arabskimi stanowiły osobiste kontakty z ich przywódcami. Premier Erdoğan chętnie i często spotykał się, na przykład, z prezydentem Syrii Baszszarem al-Asadem. Turcja nie była przygotowana na nagłe zmiany personalne, jak odsunięcie od władzy Hosni Mubaraka oraz zmianę układu sił w regionie. Ahmet Davutoğlu nie mógł i nie przewidział takiego rozwoju wydarzeń na Bliskim Wschodzie. W rezultacie podważone zostały podstawowe założenia tureckiej polityki zagranicznej, czego dowiódł zwłaszcza przypadek Syrii.

W przypadku Tunezji, turecki rząd zajął stanowisko wyczekujące, nie opowiadając się po żadnej ze stron. W grudniu 2010 r. nikt nie mógł jeszcze przewidzieć, że wydarzenia w Tunezji wywołają efekt domina na obszarze MENA. Ostatecznie Ankara poparła opozycję, ale stało się to dopiero wtedy, gdy Ben Ali stracił rzeczywistą władzę w państwie. Również w przypadku Egiptu tureckie władze stanęły przed dylematem czy wspierać reżim Mubaraka, czy też stanąć po stronie protestujących Egipcjan. Jednak o ile w przypadku Tunezji premier Erdoğan zwlekał z oficjalnym udzieleniem poparcia opozycji, o tyle w przypadku Egiptu Turcja przyjęła postawę aktywną. Zanim uczynili to przedstawiciele innych państw, turecki premier oficjalnie wezwał Hosni Mubaraka do spełnienia postulatów demonstrantów i rezygnacji z urzędu. Zdaniem Alego Omidiego, tureckie władze szybko wyciągnęły wnioski z rozwoju sytuacji i dostrzegły szansę na przejęcie władzy w Egipcie przez Bractwo Muzułmańskie. Dzięki temu Turcja mogłaby promować swój model ustrojowy, tzw. model turecki, w regionie. Ponadto, zachowałaby silnego sojusznika w świecie arabskim i tym samym ugruntowałaby swoją pozycję międzynarodową po zakończeniu procesu zmian politycznych w regionie (Omidi, 2012: 33).

Graham E. Fuller twierdzi, że Turcja była niekonsekwentna w swych działaniach. $\mathrm{Z}$ jednej strony zakładała utrzymanie dobrych, przyjaznych stosunków z państwami $\mathrm{w}$ regionie, $\mathrm{z}$ drugiej natomiast wspierała procesy demokratycznych zmian $\mathrm{w}$ tychże państwach. Jednocześnie czyniła wszystko, by zapobiec jakiejkolwiek ingerencji ze strony Zachodu (Fuller, 2014: 194). W przypadku Egiptu, podobnie jak miało to później miejsce także w Syrii i Libii, tureckie władze ostatecznie poparły protestujących. Niemniej, zanim Turcja zajęła oficjalne stanowisko w sprawie, jej władze ostrożnie analizowały rozwój sytuacji. Demonstranci uzyskali polityczne wsparcie dopiero w momencie, gdy ich sukces był przesądzony. Decyzję Turcji można było zatem określić jako pragmatyczną i racjonalną. Priorytet nadal stanowiło unikanie jakichkolwiek antagonizmów w regionie. Turecki rząd chciał być również przygotowany na możliwość pozostania $\mathrm{H}$. Mubaraka na stanowisku.

Gdy w 2012 r. do władzy doszli członkowie Bractwa Muzutmańskiego, z prezydentem Mursim na czele, władze Turcji udzieliły im politycznego poparcia. Jak się miało wkrótce okazać, cena tego poparcia okazała się być wyjątkowo wysoką. Władze Turcji jednoznacznie potępiły zamach stanu, odsunięcie od władzy Bractwa i faktyczne przejęcie władzy w Egipcie przez armię w lipcu 2013 r. Tureckie stanowisko doprowadziło 
do kryzysu dyplomatycznego, którego kulminacyjny moment stanowiło wydalenie ambasadora Turcji z Kairu pod koniec listopada. W opinii niektórych badaczy, kazus egipski jest jednym z dowodów niepowodzenia tureckiej koncepcji tzw. strategicznej głębi (Kaczorowski, 2014: 215). A przecież jeszcze kilka miesięcy wcześniej turecki model rządów był przedstawiany jako wzór dla Bractwa Muzułmańskiego (Pupcenoks, 2012). Przy okazji należy jednak dodać, że w rzeczywistości samo egipskie Bractwo Muzułmańskie krytycznie odnosiło się do modelu tureckiego. Lawrence Rubin podkreśla, iż tylko początkowo premier Erdoğan był witany w regionie niczym bohater. Gdy podczas wizyty w Egipcie zaczął doradzać członkom Bractwa Muzutmańskiego, by ci nie obawiali się sekularyzmu, zostało to przez nich odebrane jako próba narzucenia obcych rozwiązań ustrojowych i wezwanie do przyjęcia sekularyzmu (Rubin, 2014: 124).

Należy dostrzec także inny, istotny paradoks w ramach tureckiej polityki zagranicznej. Podczas gdy Turcja oficjalnie wspierała opozycję w państwach arabskich, jednocześnie tureckie władze czyniły wszystko, by zapobiec realizacji podobnego scenariusza na własnym terytorium. Najlepszy przykład stanowić mogły, między innymi, brutalne pacyfikacje demonstrantów podczas protestów w czerwcu 2013 roku. Ich symbolem stał się stambulski plac Taksim oraz przyległy do niego park Gezi. Rząd Recepa Tayyipa Erdoğana wyciagnął wnioski z doświadczeń wielu arabskich reżimów i od samego początku postawił na użycie siły oraz zastosował szereg form represji.

Wspieranie Egiptu stało także w sprzeczności z celami tureckiej polityki zagranicznej, zwłaszcza w kontekście umacniania pozycji Turcji jako regionalnego mocarstwa. Bez wątpienia Egipt był i jest jednym z największych konkurentów Turcji na Bliskim Wschodzie, zwłaszcza jeśli wziąć pod uwagę wpływy w świecie arabskim. Ponadto, wyraźne zaangażowanie polityczne oraz umacnianie związków z nowymi władzami Egiptu groziło konfrontacją z interesami i planami innych państw, na przykład, Islamskiej Republiki Iranu czy też niektórych, wpływowych państw arabskich, na przykład, Kataru. Niemniej, do zamachu stanu z lipca 2013 roku, stosunki egipsko-tureckie można było uznać za co najmniej dobre. Władze Turcji zdawały sobie sprawę z tego, iż współpracując z Egiptem mogły wzmocnić swoją pozycję w regionie, natomiast konfrontacja groziłaby jej osłabieniem.

Oceniając rozwój sytuacji w latach 2011-2015 można stwierdzić, iż Turcja jest jednym z tych państw, które najwięcej straciły na polityce prowadzonej względem Egiptu. Na początku 2015 r. oba państwa zdecydowanie więcej dzieli aniżeli łączy. Egipski ambasador został uznany w Turcji za persona non grata, a turecki wydalony z Egiptu. Politycy obu państw odwołują się także do ostrej retoryki, na przykład, Egipcjanie zarzucają Turkom brak uznania mordu Ormian z 1915 r. za zbrodnię ludobójstwa, a także ingerencję w sprawy wewnętrzne i próby destabilizowania sytuacji w Egipcie, poprzez wspieranie zdelegalizowanych organizacji. Rzecznik MSZ Egiptu, Badr Abdelatty, stwierdził publicznie, iż Turcja próbuje wpływać na egipską opinię publiczną poprzez wspieranie działalności organizacji, które mają na celu destabilizację państwa (Egypt expels, 2013). Z kolei prezydent Turcji Recep Tayyip Erdoğan określa prezydenta Sisiego mianem tyrana i publicznie domaga się uwolnienia jego poprzednika - Mohammeda Mursiego. Podczas jednego z wystąpień oświadczył: „Nigdy nie będę szanował tych, którzy zdobyli władzę na drodze wojskowego przewrotu" (Egypt expels, 2013). Rolę Turcji potwierdzał Ahmet Uysal, którego zdaniem jedynie rządy Turcji, Libii 
i Kataru dobrze życzyły demokratycznemu Egiptowi, a Turcja postrzegała demokrację w Egipcie jako warunek jego dalszego rozwoju (Uysal, 2013).

Tym samym można zakładać, że dopóki partia AKP pozostanie u władzy w Turcji, a prezydent Sisi głową państwa w Egipcie, trudno spodziewać się normalizacji we wzajemnych stosunkach dyplomatycznych. Jednocześnie należy jednak wyraźnie podkreślić, że prezydent Erdoğan znany jest z pragmatyzmu oraz częstych zmian stanowisk. Istnieje zatem prawdopodobieństwo nawiązania współpracy politycznej pomiędzy Turcją a Egiptem. Szansę stanowią, na przykład, coraz bardziej spójne stanowiska obu państw odnośnie zwalczania ISIS, choć turecka polityka względem tzw. Państwa Islamskiego nie jest jednoznaczna (Yegin, Özertem, 2014).

\section{STANOWISKO ISLAMSKIEJ REPUBLIKI IRANU}

Nagłe zmiany polityczne w państwach arabskich stanowiły zaskoczenie także dla władz Islamskiej Republiki Iranu. Mogły zostać przez nie zinterpretowane w dwojaki sposób - albo jako źródło zagrożenia dla trwałości irańskiego systemu politycznego, jeśli miałyby stanowić inspirację dla opozycji w Iranie, albo jako szansa na zwiększenie wpływów Iranu w świecie arabskim, na przykład, dzięki wsparciu udzielonemu nowym władzom. W tym kontekście pojawiła się także kwestia sytuacji mniejszości szyickiej, na przykład, w Egipcie czy Syrii, albo większości, jaką wyznawcy szyizmu stanowią w Bahrajnie. Zmiany w państwach arabskich mogły też, zgodnie z irańskimi założeniami, doprowadzić do osłabienia wpływów Zachodu w regionie, zwłaszcza amerykańskich (Marashi, Parsi, 2013: 133).

Irańskie władze dostrzegły szansę wzmocnienia swej regionalnej pozycji, wykorzystując zmiany polityczne w państwach arabskich. Teheran sprzeciwiał się jedynie antyrządowym wystapieniom w Syrii (Parsi, Marashi, 2011: 103). W przypadku Egiptu, Najwyższy Przywódca Duchowy Ali Chamenei uznał, że lepszym rozwiązaniem będzie poparcie egipskiej opozycji, zwłaszcza że prezydent Mubarak był postrzegany przez irańskie władze jako wróg. Podstawowy zarzut dotyczył jego bliskiej współpracy z Izraelem oraz USA. Zmiana reżimu stanowiła szansę na pogorszenie relacji Kairu z władzami wymienionych państw, a tym samym, jednocześnie, na wzmocnienie pozycji Iranu na Bliskim Wschodzie. Ponadto, Ali Chamenei uznał wydarzenia w Egipcie i innych państwach regionu jako przejaw wybuchu gniewu muzułmanów w świecie arabskim. W odniesieniu do tych wydarzeń zastosował zresztą znamienne określenie - islamskie przebudzenie (ang. the Islamic Awakening). Tym samym pojawiły się interpretacje, ukazujące proces przemian politycznych w państwach arabskich jako swego rodzaju kontynuację procesu rewolucyjnego, zapoczątkowanego w Iranie w 1979 r. (Ayoob, 2014: 411).

Nie można jednak pominąć faktu, iż wkrótce po sukcesie egipskich demonstrantów, miały miejsce protesty na ulicach Teheranu, które niemalże natychmiast zostały stłumione przez basidżów. Ich uczestnicy nawiązywali do zmian politycznych w Egipcie oraz Tunezji. Jednakże, jak słusznie zauważył Jerzy Zdanowski, uczestników protestów w Iranie oraz państwach arabskich różniło wiele. Co najistotniejsze, „w Egipcie opozycja narodziła się poza establishmentem, a w Iranie jest jego częścią" (Zdanowski, 
2011: 206). W tym kontekście należy wspomnieć o wydarzeniach z 2009 r. oraz fali protestów w ramach tzw. zielonego ruchu. Wówczas protestujący Irańczycy, na czele z Mirem Hosejnem Musawim, domagali się nie tyle zmiany systemu, lecz zmiany elity rządzącej, a zwłaszcza odsunięcia od władzy prezydenta Mahmuda Ahmadineżada, którego wyborcze zwycięstwo uważali za sfałszowane.

W przypadku Egiptu, nagła zmiana polityczna i będące jej konsekwencją odsunięcie od władzy Hosni Mubaraka, stanowiły szansę na poprawę stosunków egipsko-irańskich. Przedstawiciele Iranu od samego początku wspierali egipskich demonstrantów, a sam Mubarak był określany, w oficjalnych oświadczeniach, mianem faraona Egiptu (Omidi, 2012: 37). Poprawa stosunków nastąpiła już w pierwszych miesiącach $2011 \mathrm{r}$. Jej przykład stanowiła, udzielona po raz pierwszy od trzydziestu lat, zgoda egipskich władz na tranzyt irańskich okrętów wojennych przez Kanał Sueski (Maloney, 2011: 262). Późniejsze dojście do władzy Bractwa Muzułmańskiego stwarzało zatem okazję do normalizacji wzajemnych relacji, pomimo różnic o charakterze ideologicznym. Jeden z ważniejszych elementów zbliżenia stanowiły wizyty wysokiego szczebla, które nie byłyby możliwe za rządów Mubaraka. W tym kontekście warto wspomnieć przede wszystkim o pobycie prezydenta Ahmadineżada w Kairze. W opinii Lawrence'a Rubina, wizyta Ahmadineżada wywołała w Kairze skrajne emocje i ostatecznie zakończyła się fiaskiem. Demonstranci rzucali w niego butami, a jeden z najważniejszych duchownych krytykował go publicznie (Rubin, 2014: 121). Niemniej, nawet takie incydenty nie wpłynęły na zmianę oceny zbliżenia irańsko-egipskiego przez inne państwa w regionie i poza nim, zwłaszcza przez Arabię Saudyjską.

Najbardziej zaniepokojone dyplomatycznym zbliżeniem między Egiptem i Iranem były Stany Zjednoczone oraz Izrael. Zamach stanu z lipca 2013 r. oddalił groźbę zmiany układu sił w regionie i ponownie zantagonizował Egipt z Iranem. Iran nie uznał zmiany na stanowisku prezydenckim i otwarcie skrytykował aresztowanie prezydenta Mursiego. Polem rywalizacji pomiędzy Iranem a Egiptem stał się Jemen, po tym jak egipskie władze wsparły prowadzoną przez Arabię Saudyjską interwencję wojskową w tym państwie.

\section{BAHRAJN}

Jednym z państw, którego władze były żywotnio zainteresowane rozwojem sytuacji w Egipcie, był Bahrajn. Król Hamad bin Isa Al Khalifa obawiał się, iż sukces egipskich demonstrantów mógłby zachęcić część jego podwładnych do otwartego wystapienia albo z żądaniami reform ustrojowych, albo wręcz z żądaniami jego ustąpienia. Ponadto, niebezpieczne było również ewentualne przejęcie rządów w Egipcie przez Bractwo Muzułmańskie. Egipt mógłby próbować ingerować w wewnętrzne sprawy innych państw arabskich i nakłaniać ich obywateli do odrzucenia monarchii. Obawy władz Bahrajnu wydały się potwierdzać wraz z pojawieniem się pierwszych demonstrantów na ulicach stołecznej Manamy. Opozycję tworzyli przede wszystkim szyici, mogący liczyć na polityczne wsparcie ze strony władz Iranu. Hamad bin Isa Al. Khalifa wyciągnął jednak wnioski z błędów popełnionych przez H. Mubaraka i zdecydował się na siłową konfrontację z demonstrantami, w czym wymiernie wsparły go władze Arabii Saudyjskiej 
oraz Zjednoczonych Emiratów Arabskich, wysyłając własne oddziały wojskowe do Bahrajnu. Zdaniem Radosława Banii, „wydarzenia, które rozpoczęły się masowymi protestami w stolicy Bahrajnu Manamie, chociaż w bezpośredni sposób zostały sprowokowane upadkiem rządów prezydenta Egiptu Hosni Mubaraka, powinny być rozpatrywane jako jeden z elementów cyklicznych wstrząsów społeczno-politycznych, jakim kraj ten jest poddawany od momentu uzyskania niepodległości” (Bania, 2014: 204).

Dojście do władzy w Egipcie członków Bractwa Muzułmańskiego zostało odebrane w Bahrajnie jako kolejny czynnik destabilizujący sytuację w regionie. Monarcha Bahrajnu podzielał punkt widzenia przywódców Arabii Saudyjskiej oraz ZEA, natomiast z obawą obserwował wsparcie udzielane nowym egipskim władzom przez sąsiedni Katar. Sytuacja zmieniła się po zamachu stanu w Egipcie z lipca 2013 r. Król Bahrajnu udzielił poparcia nowym władzom, z generałem Sisim na czele. W marcu 2015 r. władze Egiptu i Bahrajnu zajęły takie samo stanowisko w sprawie interwencji w Jemenie.

\section{ARABIA SAUDYJSKA}

Zaniepokojona rozwojem wydarzeń w Egipcie była zwłaszcza Arabia Saudyjska. Kolejne miesiące dowiodły, że obawy elity rządzącej, dotyczące możliwości rozprzestrzeniania się fali protestów w regionie, były uzasadnione. Wystarczy wspomnieć o gwałtownym przebiegu demonstracji w sąsiednim Bahrajnie czy też, co najważniejsze, o protestach we wschodniej, zdominowanej przez szyitów, części Arabii Saudyjskiej (Matthiesen, 2012: 628).

Jak słusznie zauważył Artur Pohl, ,w przypadku Tunezji i Egiptu, Arabia Saudyjska stawała po stronie dotychczasowych reżimów, z którymi utrzymywała dobre stosunki, nie podejmując jednak żadnych działań przeciwko manifestantom. Saudyjczycy do końca popierali reżimy Mubaraka i Ben Alego, a tego ostatniego gościli po odsunięciu od władzy i ucieczce z kraju" (Pohl, 2014: 152). W przypadku Hosni Mubaraka, w jego obronę zaangażował się osobiście król Arabii Saudyjskiej Abdullah. Pod koniec stycznia 2011 roku oświadczył, w bardzo zdecydowanym tonie, między innymi: „Żaden Arab czy muzułmanin nie może tolerować jakiegokolwiek mieszania się w kwestie bezpieczeństwa i stabilności arabskiego, muzułmańskiego Egiptu ze strony tych, którzy infiltrują naród w imię wolności słowa, przebiegle ją wykorzystując" (Saudi king, 2011). Tym samym, paradoksalnie, największymi stronnikami egipskiego prezydenta w regionie stały się Arabia Saudyjska oraz Izrael, które kierowały się jednak zupełnie odmiennymi, partykularnymi interesami.

Arabia Saudyjska obawiała się dojścia do władzy egipskiego Bractwa Muzułmańskiego. Chociaż w przeszłości niejednokrotnie udzielała schronienia jego członkom, prześladowanym między innymi w Egipcie, obecnie traktuje ich jako źródło zagrożenia dla bezpieczeństwa wewnętrznego oraz regionalnego. Właśnie tym można uzasadnić saudyjską akceptację dla zamachu stanu z lipca 2013 r. Jednocześnie odsunięcie od władzy prezydenta Mursiego zmniejszyło wpływy Kataru, Turcji i Iranu w Egipcie, co również było bardzo korzystne dla Saudyjczyków. Jak twierdzi Thanassis Cambanis, „Arabia Saudyjska, wraz z innymi państwami Zatoki Perskiej, wydała ponad 12 mi- 
liardów USD, by zapewnić Sisiemu zdobycie władzy, a także obiecała kolejne wpłaty, by pomóc mu utrzymać stanowisko" (Cambanis, 2015: 248).

Wsparcie finansowe dla prezydenta Sisiego i jego stronników już przynosi Arabii Saudyjskiej wymierne korzyści. Najlepszy dowód stanowi polityczne i militarne zaangażowanie Egiptu w rozpoczętą pod koniec marca 2015 r. operację Decisive Storm. Zainicjowana i prowadzona przez Arabię Saudyjską interwencja zbrojna w Jemenie stanowi przykład pogwałcenia zasad Karty NZ, a jednak jej władzom udało się uzyskać poparcie zarówno ze strony USA, jak i większości państw arabskich, w tym Egiptu. Tym samym Egipt został włączony także w szerszą, regionalną rywalizację irańsko-saudyjską.

\section{ZJEDNOCZONE EMIRATY ARABSKIE, KUWEJT I OMAN}

Emir Kuwejtu Sabah IV Ahmad Al-Jaber Al-Sabah jednoznacznie potępił antyrządowe wystapienia na początku 2011 r. i jednocześnie zapewnił prezydenta Egiptu o swym poparciu (Al Diwan, 2011). Niemniej, wkrótce po ustapieniu Mubaraka, Kuwejt zajął bardziej pragmatyczne stanowisko, licząc na zyski z bieżących i potencjalnych inwestycji. W tym celu utworzony został specjalny fundusz inwestycyjny, z kapitałem początkowym na poziomie 1 mld USD. Podobną decyzję podjął zarząd Kharafi Group, który jeszcze przed 2010 r. zainwestował w Egipcie ponad 7 mld USD. W kwietniu Kharafi przeznaczyła na inwestycje nad Nilem kolejnych $80 \mathrm{mln}$ USD (Haniyeh, 2012: 135).

Z kolei władzom ZEA zarzucano, iż państwo to wyraźnie zyskało na niestabilności i problemach państw objętych arabską wiosną, w tym Egiptu. W odpowiedzi emir Dubaju, wiceprezydent i premier Zjednoczonych Emiratów Arabskich, Mohammed bin Rashid al-Maktoum jednoznacznie odrzucił zarzuty stawiane przez niektóre państwa jakoby ZEA korzystały z niestabilności politycznej w regionie po 2010 r. W 2013 r. podczas rządowego szczytu oświadczył: „Wśród naszych strategicznych partnerów handlowych nie ma państw objętych arabską wiosną. Doprawdy, wśród naszych dziesięciu najważniejszych partnerów handlowych nie ma żadnego państwa arabskiego, z wyjątkiem Arabii Saudyjskiej. Inwestycje zagraniczne napływały do UAE szerokim strumieniem na długo przed arabską wiosną. Napływają i będą napływać" (Al-Maktoum, 2013: 69). Z drugiej strony należy jednak dostrzec duże zaangażowanie ZEA $\mathrm{w}$ przeciwdziałanie zmianom politycznym $\mathrm{w}$ regionie, postrzeganych $\mathrm{w}$ kategoriach zagrożenia dla bezpieczeństwa wewnętrznego. W tym kontekście na uwagę zasługuje zwłaszcza zdecydowane, negatywne stanowisko władz ZEA w odniesieniu do rządów Bractwa Muzułmańskiego, które doprowadziło do napięć w stosunkach z Egiptem w latach 2012-2013. W styczniu 2013 r. władze ZEA nakazały aresztowania osób powiązanych z egipskim Bractwem Muzułmańskim, oskarżając je o organizowanie tajnych spotkań, rekrutowanie nowych członków wśród egipskich imigrantów, zbieranie pieniędzy oraz szpiegostwo. Ostatecznie 94 osobom wytoczono procesy, które doprowadziły do napięć w stosunkach dwustronnych z Egiptem (Rubin, 2014: 121). Szef policji w Dubaju, Dhahi Khalafan, stwierdził nawet, iż „Bractwo stanowi większe zagrożenie niż Iran” (Rubin, 2014: 121). 
Podobnie jak Bahrajn, także Oman stał się areną antyrządowych wystapień, które udało się jednak w porę stłumić przy wykorzystaniu szeregu środków (Maloney, 2011: 181). Władze Omanu postrzegały sukces egipskiej rewolucji za główne źródło niepokojów na własnym terytorium. Już przedtem sułtan Omanu, Qaboos bin Said Al Said, postrzegał rewolucję egipską w kategoriach zagrożenia, ze względu na możliwy efekt domina oraz wybuch gwałtownych antyrządowych protestów w wielu państwach Bliskiego Wschodu.

W rezultacie polityka Kuwejtu, Zjednoczonych Emiratów Arabskich oraz Omanu względem Egiptu, zwłaszcza na przełomie 2012 i 2013 roku, stanowiła wypadkową obaw arabskich monarchii przed wzrostem popularności idei głoszonych przez Bractwo Muzułmańskie. Tym należy tłumaczyć ich zdecydowane działania podejmowane w stosunku do sympatyków Bractwa, a także poparcie udzielone generałowi Sisiemu w trakcie i po przewrocie w lipcu $2013 \mathrm{r}$. W opinii Mohammed Abdela Kabera, ambicje polityczne egipskiego Bractwa Muzułmańskiego budziły obawy w monarchiach arabskich, związane z możliwym eksportem idei rewolucyjnych, tym razem niezwiązanych już z działalnością Iranu po 1979 roku, lecz „arabskim islamizmem” (Kader, 2014: 408).

\section{KATAR}

W przeciwieństwie do, na przykład, Arabii Saudyjskiej, władze Kataru postrzegały zmiany polityczne w wielu państwach arabskich jako szansę na wzmocnienie swych wpływów oraz realizację rozmaitych interesów. Między innymi z tego powodu zdecydowały się udzielić poparcia opozycji w Tunezji, Syrii, Jemenie, Libii oraz Egipcie. Katar z satysfakcją zaakceptował zmianę władzy w Egipcie, ze względu na wcześniejsze, napięte relacje z Mubarakiem (Anderson, 2013: 31). Z tego samego powodu Katarczycy poparli opozycję w Libii, której przywódca, Muammar Al Kaddafi, był jednym z największych krytyków polityki Kataru w świecie arabskim.

W większości przypadków Katarczycy udzielali pomocy przede wszystkim członkom Bractwa Muzułmańskiego oraz ugrupowań politycznych, grupujących islamistów (Katulis, 2013). W przypadku Egiptu, Katar wspierał egipskie władze zdominowane przez Bractwo, głównie finansowo, i udzielał szerokiego, politycznego wsparcia prezydentowi Mursiemu. Co znamienne, wkrótce po przewrocie z lipca 2013 r., władze Kataru podjęły decyzję o całkowitym wstrzymaniu pomocy gospodarczej dla Egiptu. Nie uznały także zmian politycznych oraz potępiły aresztowanie Mursiego (Badawi, Farid, 2013). Jak podkreślił Hiszam Ben Abdallah El-Alawi, również po 2013 r. „Katar próbował opowiedzieć się po stronie Braci Muzułmanów, lecz Arabia Saudyjska i Zjednoczone Emiraty Arabskie widzą w nich zagrożenie. Mimo wzrostu napięcia w relacjach z Katarem kraje te od momentu zamachu stanu przekazały Egiptowi miliardy dolarów pomocy ekonomicznej (El-Alawi, 2015: 27).

Tym samym, po dojściu do władzy prezydenta Sisiego, Katar stracił wpływy w Egipcie. Przejawem narastającego napięcia w ramach stosunków dwustronnych stało się odwołanie ambasadora Kataru z Kairu, po tym jak przedstawiciel Egiptu, na forum Ligi Państw Arabskich, miał oskarżyć Katar o wspieranie grup terrorystycz- 
nych. Incydent miał miejsce w lutym 2015 r., kilka dni po tym, gdy Egipt zaczął bombardować pozycje bojowników ISIS w sąsiedniej Libii (Egypt seeks, 2015). Ponadto, wcześniej, przez ponad rok, egipskie władze więziły ekipę dziennikarzy, pracujących dla katarskiej stacji Al-Jazeera (Egypt Al Jazeera, 2015).

$* * *$

Zmiany polityczne w Egipcie doprowadziły do istotnych zmian w skali regionalnej i spotkały się ze zrozumiałym zainteresowaniem ze strony władz najważniejszych państw Bliskiego Wschodu. Do rezygnacji ze stanowiska został zmuszony prezydent Hosni Mubarak, który przez blisko 30 lat był jednym z najważniejszych i najbardziej wpływowych polityków w regionie. Gdy rozpoczynała się egipska rewolucja, H. Mubarak mógł liczyć na poparcie kilku ważnych graczy w regionie, w tym, co ciekawe, ze strony zarówno Arabii Saudyjskiej, jak i Izraela.

Przywódcy niektórych państw bliskowschodnich, ze szczególnym uwzględnieniem monarchów z rejonu Zatoki Perskiej, z niepokojem śledzili doniesienia z Kairu. Hosni Mubarak, w odróżnieniu od sił opozycyjnych, stanowił gwarancję stabilnych i przewidywalnych rządów. Z kolei sukces egipskich demonstrantów mógł stanowić przykład i zachętę dla niezadowolonych z własnych władz mieszkańców Bahrajnu, Omanu lub Arabii Saudyjskiej. Ryzyko wybuchu podobnych, antyrządowych protestów na masową skalę było równie prawdopodobne także w przypadku Iranu oraz Turcji. Przywódcy wymienionych państw wyciagnęli jednak odpowiednie wnioski z doświadczeń zarówno Ben Alego w Tunezji, jak i Hosni Mubaraka w Egipcie. Świadczyć o tym może, między innymi, brutalna pacyfikacja protestujących na stambulskim placu Taksim oraz siłowe zdławienie protestów w Bahrajnie.

Równie zaniepokojone rozwojem wydarzeń były władze sąsiedniego Izraela, dla którego nagła zmiana polityczna w Egipcie mogła być szczególnie dotkliwa. Egipska opozycja nie mogła zatem liczyć na poparcie ze strony izraelskich władz, lecz nie stanowiło to dlań żadnego problemu. Wręcz przeciwnie, takie wsparcie mogłoby ją jedynie zdyskredytować w oczach części społeczeństwa. Tym samym, w przekonaniu Izraelczyków, najkorzystniejszy scenariusz zakładał pozostanie u władzy prezydenta Mubaraka. Izraelskie władze obawiały się przejęcia rządów albo przez Bractwo $\mathrm{Mu}$ zutmańskie, albo przez islamistów. Na początku 2011 roku powszechne było przekonanie, iż realizacja takiego scenariusza zagrażała ciagłości dwustronnych stosunków dyplomatycznych. Co więcej, niekontrolowany rozwój wydarzeń w Egipcie mógłby zagrozić pokojowi w regionie i doprowadzić do ponownego, prawie całkowitego otoczenia Izraela przez wrogie arabskie reżimy. Wyjątek stanowiłaby, nie wiadomo też na jak długo, Jordania. W związku z powyższym izraelskie władze poważnie obawiały się powrotu do sytuacji z pierwszej połowy lat 70 . XX wieku. Zerwanie kontraktu gazowego przez Egipt w 2012 r. wydawało się te obawy potwierdzać. Wielu analityków przewidywało, iż był to jedynie wstęp do poważnych napięć dyplomatycznych. Tymczasem sytuacja uległa znaczącej poprawie po odsunięciu od władzy członków Bractwa Muzułmańskiego i dojściu do władzy Sisiego.

Podsumowując; na egipskich zmianach politycznych w 2011 r. najwięcej zyskały Turcja oraz Iran, natomiast najwięcej stracił Izrael. Sytuacja odwróciła się jednak po 
zamachu stanu z lipca 2013 r. Izrael odzyskał swoją pozycję, zwłaszcza w sferze gospodarczej, natomiast Turcja i Iran straciły wpływy polityczne, którymi dysponowały w okresie rządów Bractwa Muzułmańskiego. Podobnie stało się w przypadku Kataru, natomiast Arabia Saudyjska oraz pozostałe monarchie z rejonu Zatoki Perskiej wyraźnie zyskały na przejęciu władzy przez generała Sisiego. Wpływ decyzji, podjętych w latach 2011 i 2013, na stan stosunków dwustronnych na początku 2015 r., obrazuje poniższa tabela.

Tabela 1

\begin{tabular}{||l|c|c|c||}
\hline Nazwa państwa & $\begin{array}{c}\text { Stosunek do zmian } \\
\text { politycznych } \\
\text { w Egipcie w 2011 r. } \\
\text { (+/-) pozytywny/ne- } \\
\text { gatywny }\end{array}$ & $\begin{array}{c}\text { Stosunek do zmian } \\
\text { politycznych } \\
\text { w Egipcie w 2013 r. } \\
(+/-) \text { pozytywny/ne- } \\
\text { gatywny }\end{array}$ & $\begin{array}{c}\text { Stan stosunków dwu- } \\
\text { stronnych z Egiptem } \\
\text { worównaniu z okresem } \\
\text { 2012-2013 (marzec 2015) } \\
\text { (+/-) pozytywny/nega- } \\
\text { tywny }\end{array}$ \\
\hline Arabia Saudyjska & - & + & + \\
\hline Bahrajn & - & + & + \\
\hline Islamska Republika Iranu & + & - & + \\
\hline Izrael & - & - & + \\
\hline Katar & - & + & + \\
\hline Kuwejt & - & + & + \\
\hline Oman & + & + & + \\
\hline Turcja & - & + & + \\
\hline Zjednoczone Emiraty \\
Arabskie
\end{tabular}

Źródło: Opracowanie własne.

\section{Bibliografia}

Adib-Moghaddam A. (2014), On the Arab Revolts and the Iranian Revolution: Power and Resistance Today, New York.

Al-Maktoum M. bin Rashid (2013), Flashes of Thought: Inspired by a Dialogue at the Government Summit 2013, Dubai.

Anderson L. (2013), Early Adopters and Neighbourhood Effects, w: The Arab Spring: Will It Lead to Democratic Transitions?, (eds.) C. Henry, J. Ji-Hyang, New York.

Ayoob M. (2014), Turkey and Iran in the Era of the Arab Uprisings, w: The New Middle East: Protest and Revolution in the Arab World, (ed.) F. A. Gerges, Cambridge.

Badawi N., Farid D. (2013), Following Morsi's ouster, Qatar's support to Egypt in question, http:/www.dailynewsegypt.com/2013/07/14/following-morsis-ouster-qatars-support-to-egypt-in-question/ (11.02.2015).

Bania R. (2014), „Arabska Wiosna” - doświadczenia arabskich monarchii subregionu Zatoki Perskiej, „Przegląd Politologiczny”, nr 1, [DOI: 10.14746/pp.2014.19.1.13].

Ben-Meir A. (2014), Spring or Cruel Winter? The Evolution of the Arab Revolutions, Washington D.C. 
Cambanis T. (2015), Once Upon A Revolution: An Egyptian Story, New York.

Davutoğlu A. (2001), Stratejik derinlik: Türkiye’nin uluslararasý konumu, Istanbul.

Egypt expels Turkish ambassador, Turkey retaliates (2013), http://www.reuters.com/article/2013/ 11/23/us-egypt-turkey-idUSBRE9AM03Y20131123 (30.01.2015).

Egypt seeks UN backing for air strikes against ISIS in Libya (2015), http://www.theguardian.com/world/2015/feb/17/egypt-seeks-backing-air-strikes-isis-libya (20.02.2015).

Egypt: Al Jazeera journalists released on bail (2015), http:/www.inquisitr.com/1835466/egypt-al-jazeera-journalists-released-on-bail/ (20.02.2015).

El-Alawi H. B. A. (2015), Bunty i wojny po Arabskiej Wiośnie, „Le Monde Diplomatique”, nr 3 (109).

Fuller G. E. (2014), Turkey and the Arab Spring: Leadership in the Middle East, Bozorg Press.

Haniyeh A. (2012), Egypt's Orderly Transition: International Aid and the Rush to Structural Adjustment, w: The Dawn of the Arab Uprisings: End of an Old Order?, (eds.) B. Haddad, R. Bsheer, Z. Abu-Rish, London.

Kaczorowski K. (2014), Stambulska recepcja Arabskiej Wiosny i idei ,,tureckiego modelu” demokracji, Kraków.

Kader A. B. (2014), Contradictory Paths: Islamist Experiments of Egypt and Turkey, „Turkish Review", Vol. 4, No. 4.

Katulis B. (2013), Qatar, Saudi Arabia Diverge in Battle to Shape Changing Middle East, http:/www.worldpoliticsreview.com/articles/12988/qatar-saudi-arabia-diverge-in-battle-to-shape-changing-middle-east (11.02.2015).

Kuwait Amir condemns riots, looting, sabotage in Egypt, affirms support to Egyptians, 29 January 2011 (2011), http://www.da.gov.kw/eng/newsroom/searchArchive.php (3.02.2015).

Maloney S. (2011), Iran: The Bogeyman, w: The Arab Awakening: America and the Transformation of the Middle East, (ed.) K. Pollack, Washington D.C.

Maloney S. (2011), Kuwait, Qatar, Oman, and the UAE: The Nervous Bystanders, w: The Arab Awakening: America and the Transformation of the Middle East, (red.) K. Pollack, Washington D.C.

Marashi R., Parsi T. (2013), The Gift and the Curse: Iran and the Arab Spring, w: The Arab Spring: Change and Resistance in the Middle East, (eds.) M. L. Haas, D. W. Lesch, Boulder.

Matthiesen T. (2012), A 'Saudi Spring'? The Shia Protest Movement in the Eastern Province 2011-2012, „The Middle East Journal”, Vol. 66, No. 4, [DOI: 10.3751/66.4.14 1].

Omidi A. (2012), A Comparative Analysis of the Turkish and Iranian Foreign Policy Towards the Arab Revolutions, „Discourse: An Iranian Quarterly”, No. 3-4.

Parsi T., Marashi R. (2011), Arab Spring Seen From Tehran, „Cairo Review”, No. 2.

Peres praises Mubarak for his contribution to peace, http://www.ynetnews.com/articles/ 0,7340,L-4024283,00.html (3.02.2015).

Pohl A. (2014), Arabia Saudyjska wobec Arabskiej Wiosny, „Przegląd Politologiczny”, nr 1, [DOI: 10.14746/pp.2014.19.1.9].

Pupcenoks J. (2012), Democratic Islamization in Pakistan and Turkey: Lessons for the Post-Arab Spring Muslim World, „The Middle East Journal”, Vol. 66, No. 2, [DOI: 10.3751/66.2.14].

Rabinovich I. (2014), Israel and the Arab Turmoil, Stanford.

Rubin L. (2014), Islam in the Balance: Ideational Threats in Arab Politics, Stanford.

Saudi king expresses support for Mubarak (2011), http://www.reuters.com/article/2011/01/29/ egypt-saudi-idAFLDE70S08V20110129 (3.02.2015).

Sherwood H. (2012), Egypt cancels Israeli gas contract, http://www.theguardian.com/world/2012/ apr/23/egypt-cancels-israeli-gas-contract (30.01.2015). 
Uysal A. (2013), Insights for Egypt's and Tunisia's Islamists from Turkish Experience of Democratic Transition, „Insight Turkey”, Vol. 15, No. 4.

Yegin M., Özertem H. S. (2014), Parameters of Engagement and Turkey's Limits in the Coalition Against ISIS, the German Marshall Fund of the United States' Analysis, 13.11.2014.

Zdanowski J. (2011), Bliski Wschód 2011: bunt czy rewolucja?, Kraków.

\title{
STRESZCZENIE
}

Przedmiot niniejszego artykułu stanowi szczegółowa analiza stanowisk władz najważniejszych państw bliskowschodnich, w odniesieniu do zmian na egipskiej scenie politycznej po 2011 roku: Izraela, Turcji, Islamskiej Republiki Iranu oraz państw członkowskich Rady Współpracy Zatoki Perskiej - Arabii Saudyjskiej, Bahrajnu, Zjednoczonych Emiratów Arabskich, Kataru, Omanu i Kuwejtu. Celem artykułu jest ustalenie przyczyn, dla których władze wyżej wymienionych państw zdecydowały się, bądź też nie, wesprzeć proces zmian politycznych w Egipcie w latach 2011 i 2013 r., a także konsekwencji tych decyzji z perspektywy 2015 r., zwłaszcza wpływu na obecny stan stosunków dwustronnych.

\section{ATTITUDES OF SELECTED MIDDLE EASTERN STATES TOWARDS POLITICAL CHANGES IN EGYPT: INFLUENCE ON BILATERAL RELATIONS}

\begin{abstract}
This article is dedicated to a detailed analysis of positions on political changes in Egypt after 2011 of selected, the most influential Middle Eastern actors such as Israel, Turkey, the Islamic Republic of Iran, and the Gulf Cooperation Council members, namely Saudi Arabia, Bahrain, the United Arab Emirates, Qatar, Oman, and Kuwait. The main purpose of the article is to determine reasons for their attitudes towards processes of political changes in Egypt in 2011 and in 2013 as well as consequences of these decisions and their influence on current state of bilateral affairs with Egypt.
\end{abstract}

